\title{
MODEL PREDIKSI LEVEL AIR DI LAHAN PERKEBUNAN KELAPA SAWIT DENGAN JARINGAN SARAF TIRUAN BERDASARKAN PENGUKURAN SENSOR RAIN GAUGE DAN ULTRASONIK
}

\author{
MODEL OF WATER LEVEL PREDICTION WITH ARTIFICIAL NEURAL \\ NETWORK BASED OF RAIN GAUGE MEASUREMENT AND ULTRASONIC \\ SENSOR
}

\author{
Hasan Al-Banna ${ }^{1}$ dan Bayu Dwi Apri Nugroho ${ }^{1}$ \\ ${ }^{1}$ Departemen Teknik Pertanian dan Biosistem, Fakultas Teknologi Pertanian, Universitas Gadjah Mada \\ ${ }^{\circledR}$ Komunikasi Penulis, email: hasan_albanna25@yahoo.com \\ DOI:http://dx.doi.org/10.23960/jtep-l.v10i1.104-112
}

Naskah ini diterima pada 22 Januari 2021; revisi pada 20 Februari 2021;

disetujui untuk dipublikasikan pada 8 Maret 2021

\begin{abstract}
Monitoring and regulating water levels in oil palm swamps has an essential role in providing sufficient water for crops and conserving the land to not easily or quickly deteriorate. Presently, water level is still manual and has weaknesses, one of which is the accuracy of the data taken depending on the observer. Technology such as sensors integrated with artificial neural network is expected to observe and regulate water levels. This study aims to build a prediction model of water levels in oil palm plantations with artificial neural networks based on the rain gauge and ultrasonic sensors installed on Automatic Weather Station (AWS). The obtained results showed that the prediction model runs well with an $R^{2}$ value of 0,994 and RMSE 1,16 cm. The water level prediction model in this research then tested for accuracy to prove the model's success rate. Testing the water level prediction model's accuracy in the dry season obtained an $R^{2}$ value of 0,96 and an RMSE of 1,99 cm. Testing the water level prediction model's accuracy in the rainy season obtained an $R^{2}$ value of 0,85 and an RMSE value of 4,2 cm.
\end{abstract}

Keywords : artificial neural network, automatic weather station, palm oil, water level

\begin{abstract}
ABSTRAK
Pemantauan dan pengaturan level air di lahan rawa kelapa sawit mempunyai peranan yang penting untuk menyediakan air yang cukup bagi tanaman dan melestarikan lahan agar tidak mudah atau cepat mengalami penurunan kualitas. Pemantauan level air yang ada masih bersifat manual tentunya masih memiliki kelemahan salah satunya adalah tingkat kebenaran data yang diambil tergantung pada pengamat di lahan. Penggunaan teknologi seperti sensor yang terintegrasi dengan jaringan saraf tiruan diharapkan dapat membantu dalam melakukan pengamatan dan pengaturan level air. Penelitian ini bertujuan untuk membangun model prediksi level air di lahan perkebunan kelapa sawit dengan jaringan saraf tiruan berdasarkan pengukuran sensor rain gauge dan ultrasonik yang terpasang pada AWS. Berdasarkan hasil yang diperoleh menunjukkan model prediksi berjalan dengan baik dengan nilai $\mathrm{R}^{2}$ sebesar 0,994 dan RMSE 1,16 cm. Kemudian dilakukan pengujian keakuratan model prediksi level air untuk membuktikan tingkat keberhasilan model yang dibangun. Hasil pengujian keakuratan model prediksi level air pada musim kemarau diperoleh nilai $\mathrm{R}^{2}$ sebesar 0,96 dan RMSE sebesar 1,99 cm sedangkan pengujian keakuratan model prediksi level air pada musim hujan diperoleh nilai $\mathrm{R}^{2}$ sebesar 0,85 dan nilai RMSE sebesar 4,2 $\mathrm{cm}$.
\end{abstract}

Kata Kunci : automatic weather station, jaringan saraf tiruan, kelapa sawit, level air

\section{PENDAHULUAN}

Pengembangan kelapa sawit di lahan rawa akan dihadapkan pada berbagai tantangan terkait dengan karakteristik tanah pada lahan tersebut, yaitu tantangan dalam pengelolaan lahan, kultur teknis maupun investasi untuk pembangunan infrastruktur (Suriadikarta, 2005). Kelapa sawit yang di tanam pada lahan rawa memiliki potensi untuk berkembang dengan baik didasarkan pada 
karakteristik lahan maupun luasannya, namun demikian masalah utama yang dihadapi adalah kondisi drainase yang terhambat dan tergenang. Agar perakaran tanaman kelapa sawit dapat berkembang setidaknya diperlukan lapisan yang tidak tergenang air sedalam 50 - $75 \mathrm{~cm}$ (Winarna et al., 2014).

Salah satu upaya yang dilakukan untuk mengelola air dengan baik di lahan rawa dengan melakukan pemantauan tinggi muka air atau level air (Minnesota Board of Water Level and Soil Resource, 2013). Pemantauan level air umumnya dilakukan secara manual dengan melihat bacaan yang terukur pada piezometer dan peil scale meter pada setiap saluran, hal ini tentunya memiliki berberapa kelemahan di antaranya adalah tingkat kebenaran data yang diambil tergantung pada pengamat di lahan (kesalahan pembacaan, pencatatan data hasil pengamatan yang tidak sesuai dengan kondisi yang ada).

Penggunaan alat bantu lain atau teknologi dapat menjadi solusi dalam mendukung sistem monitoring yang ada di lahan. Nugroho dan Aliwarga (2009) melakukan penelitian di Kupang (NTT) dengan memasang beberapa sensor seperti radiasi matahari, curah hujan, tanah dan kelembaban untuk mengetahui kondisi lapangan sebenarnya yang terpantau dengan citra, akusisi data numerik dan grafis. Sumardi (2005) juga melakukan penelitian dengan memasang AWS dengan memanfaatkan mikrokontroller serta beberapa sensor sebagai alat akuisisi data dan berhasil mengukur temperature, tekanan udara, kelembaban udara, arah dan kecepatan angin, energi surya, serta jumlah curah hujan.

Pengembangan AWS untuk memenuhi kebutuhan data dapat dilakukan dengan cara memodifikasi sistem akusisi data, sehingga pengambilan data dapat diperoleh secara otomatis dan real time dengan teknologi IoT. Naik dan Katti (2018) mengaplikasikan IoT pada sistem irigasi untuk meningkatkan produksi pertanian dengan kinerja yang efektif dan sistem yang aman serta memiliki dampak yang signifikan dalam memastikan penggunaan sumber daya air yang efisien. Pengunaan teknologi IoT sebagai sistem transmisi atau pengiriman data pada alat AWS tergantung pada kualitas sinyal ataupun jaringan yang ada di suatu tempat. Kekosongan data dapat terjadi akibat pengiriman data yang gagal disebabkan karena jaringan atau sinyal di suatu tempat kurang baik (Armin et al., 2017). Solusi terhadap permasalahan diatas adalah dengan cara membangun model prediksi level air.

Salah satu model prediksi yang dinilai akurat dalam menentukan variabel terikat berdasarkan banyak variabel bebas adalah model Jaringan Saraf Tiruan atau JST. JST adalah paradigma pemrosesan suatu informasi yang terinspirasi oleh sistem sel saraf biologi manusia untuk memproses suatu informasi (Siang, 2005). Keberhasilan suatu proses belajar JST ditunjukkan dengan besarnya error yang minimum. Proses belajar pada jaringan saraf tiruan ditunjukkan dengan perubahan bobot penghubung antar sel jaringan syaraf. Implementasi jaringan syaraf tiruan dilakukan dengan perangkat keras atau komputer (Hermawan, 2006). Penelitian ini bertujuan membangun model prediksi level air di lahan perkebunan kelapa sawit dengan jaringan saraf tiruan berdasarkan pengukuran sensor rain gauge dan ultrasonik yang terpasang pada AWS.

\section{BAHAN DAN METODE}

\subsection{Prosedur Penelitian}

Prosedur penelitian dimulai dari perolehan data exsisting pada objek penelitian untuk menggambarkan kondisi iklim atau cuaca berdasarkan data curah hujan pada periode 2012-2018. Lokasi penelitian yang digunakan adalah perkebunan kelapa sawit milik PT Tribuana Mas. Selanjutnya membuat model jaringan saraf tiruan prediksi level air dengan curah hujan, operasional pompa dan level air sebagai variabel bebas dan prediksi level air sebagai variabel terikat. JST dibangun menggunakan software Matlab R2014b lalu dilakukan inisialisasi jaringan.

Tahap selanjutnya adalah melakukan pengambilan data curah hujan dan level air dengan sensor rain gauge dan ultrasonik yang terpasang di AWS dan melakukan pengujian pada sensor meliputi uji kinerja sensor. Uji kinerja 
meliputi keberhasilan alat dalam sistem akusisi data, transmisi data dan keakuratan hasil pengukuran sensor. Pada pengujian transmisi data diperoleh nilai utilisasi alat pada saat pengiriman data berlangsung selama penelitian ini dilakukan. Selanjutnya dilakukan uji keakuratan hasil pengukuran sensor, pengujian ini dilakukan dengan cara membandingkan hasil pengukuran menggunakan sensor terhadap pengukuran secara manual yang ada di lahan. Kemudian menguji keakuratan model prediksi level air secara aktual berdasarkan hasil pengukuran sensor rain gauge dan sensor ultrasonik yang terpasang di AWS. Pengujian dilakukan dengan cara membuat persamaan matematika yang diperoleh dari pembuatan model JST kemudian mencari nilai error dan $\mathrm{R}^{2}$ pada hasil prediksi level air terhadap hasil observasi sensor.

\subsection{Analisis Data}

Data eksisting curah hujan periode 2012-2018 yang diperoleh dianalisis menggunakan metode Schmidt-Ferguson untuk mengklasifikasikan kondisi iklim obyek penelitian. Selanjutnya, mencari hubungan korelasi curah hujan dan level air kemudian dianalisis menggunakan regresi linear. Hubungan korelasi antar parameter menjadi dasar dalam penentuan variabel input pada pembuatan model JST.

Model JST prediksi level air yang dibangun menggunakan data periode Juli 2018-Agustus 2019. Data dibagi menjadi dua yaitu $70 \%$ digunakan sebagai data latih dan 30\% sebagai data uji. Rani dan Parekh (2014) melakukan prediksi level air pada waduk Sukhi, Gujarat, India. Model JST yang dikembangkan menggunakan input aliran air, ketinggian air pada waktu tertentu dan jumlah buangan air dengan output level air setelah satu jam berikutnya. Data untuk pembuatan model sebesar $70 \%$ dan untuk validasi sebesar 30\% dari total data yang diperoleh dari Januari 1990 sampai dengan Oktober 2013.

Kemudian melakukan analisis terkait keberhasilan model JST pediksi level air dengan melakukan pengujian keakuratan model secara aktual berdasarkan hasil pengukuran sensor rain gauge dan ultrasonik. Pada pengujian diperoleh nilai Root Mean Square Error (RMSE), Relative Root Mean Square Error (RRMSE) dan koefisien determinasi $\left(\mathrm{R}^{2}\right)$. Nilai RMSE dan RRMSE yang kecil dan $\mathrm{R}^{2}$ yang mendekati 1 menjelaskan keberhasilan model dalam memprediksi level air berdasarkan hasil pengukuran sensor.

\section{HASIL DAN PEMBAHASAN}

\subsection{Kondisi Exsisting Objek Penelitian}

PT TBM merupakan salah satu anak perusahaan dari PT Astra Agro Lestari Tbk yang memiliki lokasi di Buas Buas Hilir, Kecamatan Candi Laras Utara, Kabupaten Tapin, Kalimantan Selatan. Menurut data curah hujan selama 7 tahun yang ada di perusahan, hampir sebagian bulan ditandai dengan curah hujan yang signifikan. Gambar 1 menunjukkan rata-rata curah hujan periode 2012-2018.

Pada Gambar 1 berdasarkan hasil pengolahan data curah hujan maka rata-rata curah hujan pada periode 2012-2018 di PT TBM memiliki pola

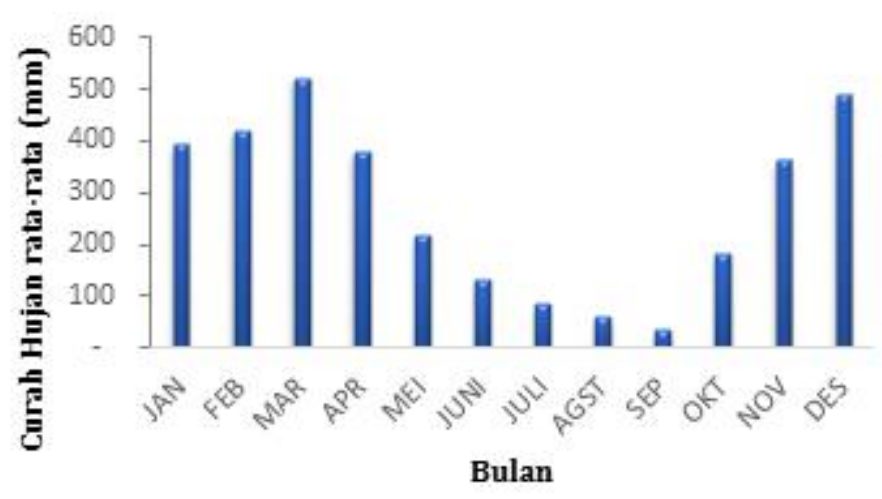

Gambar 1. Grafik Karakteristik Curah Hujan PT TBM Periode 2012-2018 
monsunal. Pola monsunal ditandai dengan intensitas curah hujan tertinggi terjadi pada awal dan akhir tahun yang bersifat unimodial (satu puncak musim hujan) berbentuk huruf V. Tipe hujan monsun di Indonesia dicirikan oleh adanya perbedaan yang jelas antara periode musim hujan dan musim kemarau (Tukidi, 2010). Curah hujan di PT TBM ditinjau secara rata-rata selama 7 tahun (2012-2018) berkisar antara $36 \mathrm{~mm}$ sampai $521 \mathrm{~mm}$ dimana curah hujan tertinggi terjadi pada bulan Maret sebesar $521 \mathrm{~mm}$ dan curah hujan terendah terjadi pada bulan September sebesar $36 \mathrm{~mm}$.

Hasil pengolahan data curah hujan diperoleh frekuensi bulan basah dan bulan kering. Menurut klasifikasi Schmidt-Ferguson kategori untuk bulan kering (jika dalam satu bulan mempunyai jumlah curah hujan $<60 \mathrm{~mm}$ ), bulan lembab (jika dalam satu bulan mempunyai jumlah curah hujan 60 sampai $100 \mathrm{~mm}$ ), dan bulan basah (jika dalam satu bulan mempunyai jumlah curah hujan $>100$ $\mathrm{mm}$ ). Hasil peneliatan dari curah hujan rata-rata selama periode 2012-2018 diperoleh bulan basah sebesar 9, bulan kering sebesar 1 dan bulan lembab sebesar 2. Dari perhitungan bulan basah dan bulan kering diperoleh nilai Q sebesar 0.11, nilai tersebut menjelaskan bahwa kondisi iklim di PT TBM termasuk tipe A dengan sifat sangat basah.

\subsection{Hubungan Curah Hujan dengan Level Air}

Curah hujan merupakan salah satu faktor yang perlu dipehatikan dalam pengaturan level air di lahan rawa. Hubungan antara curah hujan dengan level air dapat dilihat pada Gambar 2.

Gambar 2 merupakan hubungan curah hujan dengan level air yang terjadi pada periode Juli 2018 hingga Juli 2019. Pada grafik Gambar 2, koefisien korelasi (R) diperoleh sebesar 0,584; 0,$675 ; 0,461 ; 0,516$ secara berturut turut mulai dari kondisi hubungan curah hujan dan level air dari tahun 2018 hingga tahun 2019. Hal ini menunjukkan bahwa curah hujan memiliki hubungan yang cukup hingga kuat terhadap kondisi level air yang ada.

Nilai $\mathrm{R}^{2}$ yang diperoleh pada Gambar 2 menunjukkan bahwa secara umum variabel bebas yakni curah hujan mampu menjelaskan variabel terikat berupa level air pagi dan sore hari pada tahun 2018 masing-masing sebesar

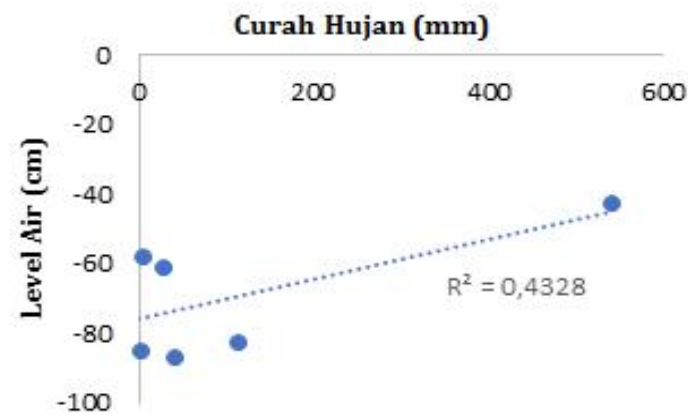

b

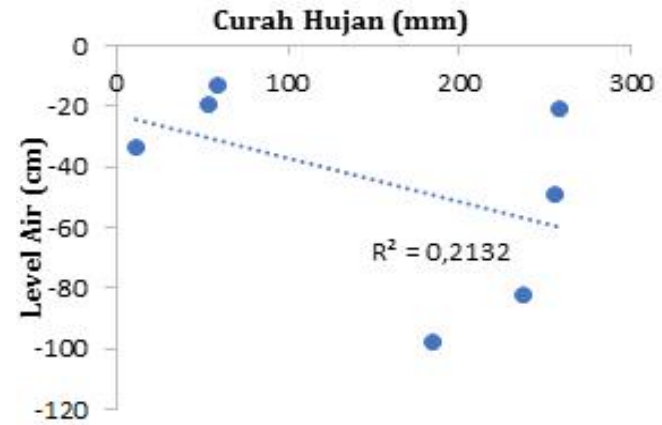

C

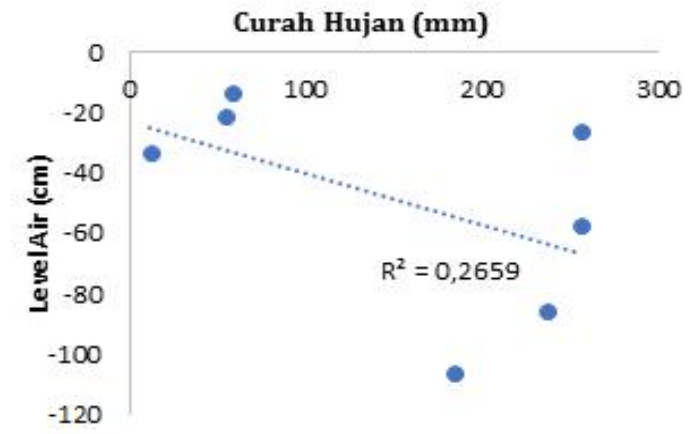

d

Gambar 2. Grafik Hubungan Curah Hujan Bulanan dan Level Air Bulanan (a) Pagi Hari Tahun 2018, (b) Sore Hari Tahun 2018, (c) Pagi Hari Tahun 2019, dan (d) Sore Hari Tahun 2019 
$34 \%$ hingga $43 \%$. Sedangkan pada tahun 2019 , level air mampu dijelaskan oleh variabel curah hujan sekitar 21\% hingga 26\%. Temuan tersebut mengindikasikan adanya faktor lain yang mempengaruhi ketinggian level air, misalnya adanya lumut dan sampah di saluran drainase sehingga membuat pembuangan air menjadi terhambat. Oleh sebab itu, analisis regresi hubungan kedua parameter tersebut menghasilkan nilai korelasi yang rendah.

\subsection{Transmisi Data Sensor}

Dalam transmisi data ini, jenis provider yang digunakan yaitu merk Telkomsel, hasil yang diperoleh dari pengiriman data selama 47 hari ada 7 hari data diantaranya tidak terkirim. Data yang tidak terkirim dikarenakan jaringan atau kualitas sinyal pada pengambilan data hari ke 1218 kurang baik. Transmisi data yang dihasilkan dapat dilihat pada Gambar 3a dan b.

Berdasarkan Gambar 3 data yang tidak terkirim dapat dilihat pada garis grafik yang terputus. Pada sistem transmisi data yang telah ditentukan, alat seharusnya mengirim data setiap 4 menit sekali dalam 1 hari, maka jika ada garis grafik yang terputus maka data tersebut tidak terkirim. Dari data yang diperoleh menandakan bahwa utilisasi sensor untuk transmisi data sebesar $85 \%$, hal ini menjelaskan bahwa kinerja sensor pada pengiriman data telah bekerja dengan baik. Tidak terkirimnya data dapat disebabkan oleh banyak hal, di antaranya jaringan yang tidak stabil, modem yang dalam keadaan panas, ataupun jenis provider yang digunakan.

\subsection{Pengujian Automatic Weather Station} Pengujian alat bertujuan untuk mendapatkan nilai error pada alat. Faktor koreksi ini nanti yang

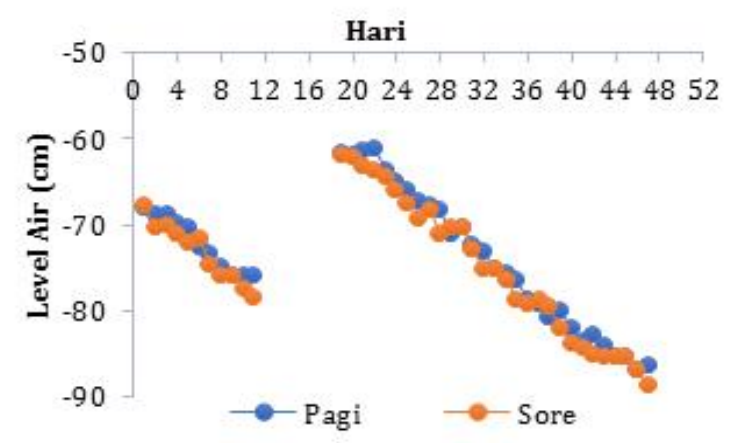

a digunakan untuk mengetahui kinerja sensor pada alat sudah relevan atau belum dibandingkan dengan pengukuran manual yang ada di lahan. Kemudian dicari nilai koefisien korelasi (R) untuk menentukan hubungan antara nilai pengukuran sensor dengan nilai pengukuran manual.

Gambar 4 menjelaskan mengenai uji kinerja sensor rain gauge untuk mengukur curah hujan dan sensor ultrasonik untuk mengukur level air. Pengujian dilakukan dengan cara membandingkan hasil pengukuran sensor dengan pengukuran manual. Hasil pengujian yang diperoleh secara berturut-turut diperoleh nilai R sebesar 0,95; 0,99; 0,99 dan nilai RMSE sebesar 0,$13 ; 0,51 ; 0,93$. Nilai koefisien korelasi (R) sebesar 0,95; 0,99; 0,99 menandakan bahwa hasil pengukuran menggunakan sensor memiliki hubungan yang sangat kuat dengan pengukuran secara manual, hal itu ditandai dengan hasil pengukuran dari sensor yang mendekati nilai pengukuran secara manual, sedangkan nilai RMSE menjelaskan bahwa hanya sedikit koreksi kesalahan yang didapat oleh sensor terhadap pengukuran manual sehingga dapat dikatakan sensor telah bekerja dengan baik.

\subsection{Model Jaringan Saraf Tiruan Prediksi Level Air}

Model JST yang dikembangkan merupakan JST tipe backpropagation. Model JST yang dikembangkan memiliki dua hidden layer dengan jumlah node 12-12-1 untuk JST prediksi level air. JST menggunakan tipe pelatihan trainlm, jumlah iterasi maksimal sebesar 1000 , learning rate sebesar 0,001 dan nilai MSE terkecil sebesar 0,00001 . Variasi fungsi aktivasi dilakukan untuk mendapatkan model terbaik untuk prediksi. Hasil

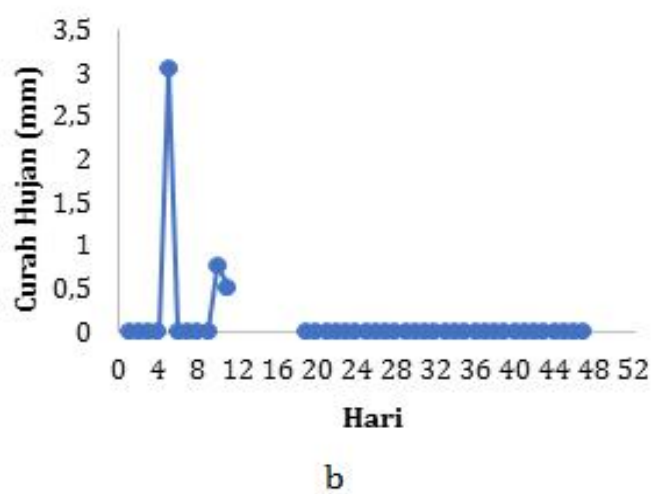

b

Gambar 3. Transmisi Data Sensor (a) Sensor Ultrasonic dan (b) Sensor Rain Gauge 


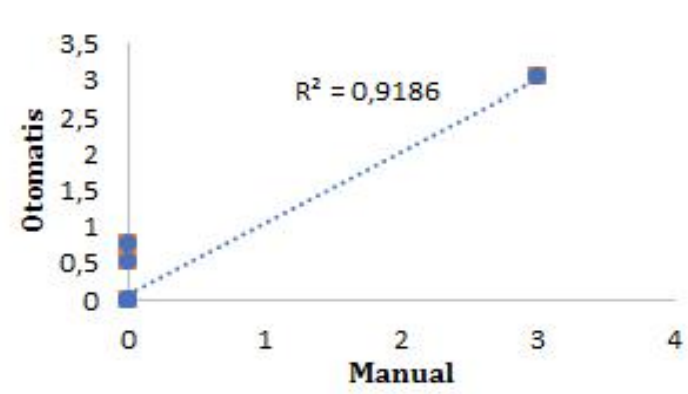

a

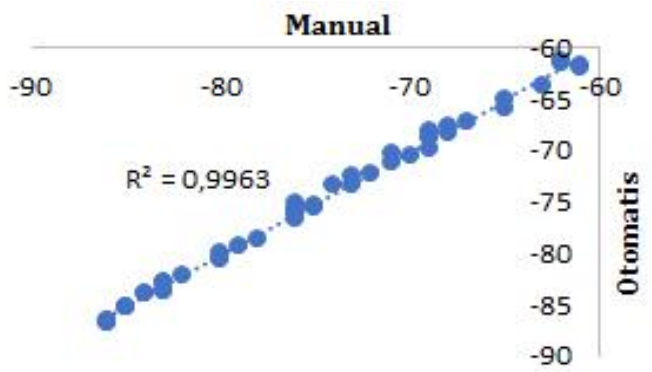

b

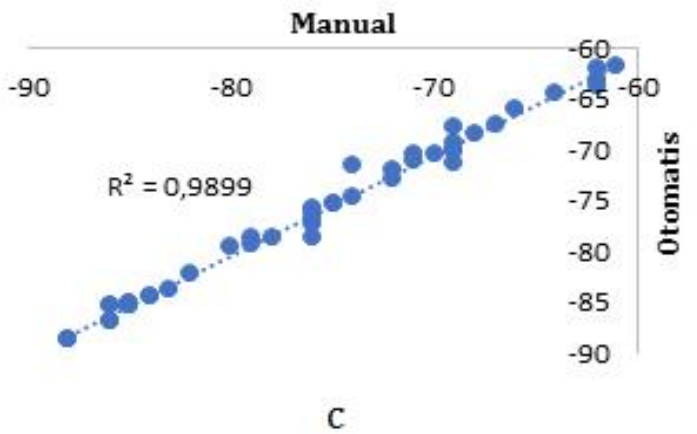

Gambar 4. Uji kinerja Sensor (a) Curah Hujan, (b) Level Air Pagi, dan (c) Level Air Sore

Tabel 1. Hasil Pengujian Model JST Level Air

\begin{tabular}{cll}
\hline Struktur Jaringan & & \multicolumn{1}{c}{ Level Air } \\
\hline Learning rate & & 0,001 \\
\hline Tipe pelatihan & & Trainlm \\
\hline \multirow{3}{*}{ Fungsi aktivasi } & $\mathrm{I}-\mathrm{HI}$ & Logsig \\
\cline { 2 - 3 } & $\mathrm{HI}-\mathrm{H} 2$ & Purelin \\
\cline { 2 - 3 } & $\mathrm{H} 2-\mathrm{O}$ & Purelin \\
\hline \multirow{3}{*}{ Jumlah node } & $\mathrm{I}-\mathrm{HI}$ & 12 \\
\cline { 2 - 3 } & $\mathrm{HI}-\mathrm{H} 2$ & 12 \\
\cline { 2 - 3 } & $\mathrm{H} 2-\mathrm{O}$ & 1 \\
\hline RMSE & & 1,6 \\
\hline RRMSE & & -2.8 \\
\hline $\mathrm{R}^{2}$ & & 0,994 \\
\hline
\end{tabular}

pengujian model JST prediksi level air dapat dilihat pada Tabel 1.

Pada Gambar 5 data yang digunakan dalam pembuatan model jaringan saraf tiruan adalah data level air PT Tribuana Mas selama rentang waktu Juli 2019-Juli 2020. Data tersebut dibagi menjadi menjadi 2 yaitu $70 \%$ data latih dan $30 \%$ data uji. Variabel input yang digunakan adalah data curah hujan, operasional pompa dan level air yang diambil 7 hari terakhir. Dari input itu akan digunakan untuk melakukan prediksi level pada hari ke 8 dan selanjutnya.
Pada Gambar 6 dapat diamati hasil dari pembuatan model model JST prediksi level air. Hasil pengujian terbaik pada JST pengukuran level air terdapat pada fungsi aktivasi logsigpurelin-purelin dengan nilai RMSE adalah $1,6 \mathrm{~cm}$, RRMSE sebesar $-2,8 \%$ dan $\mathrm{R}^{2}$ sebesar 0,994 . Nilai $\mathrm{R}^{2}$ yang diperoleh sebesar 0,994 dan nilai RRMSE sebesar -2,8\% menjelaskan bahwa dalam pembuatan model ini berjalan dengan baik karena hasil prediksi yang keluar dapat membaca tren data observasi dengan tepat dan akurat. Hasil prediksi tergolong sengat baik dengan RRMSE $<10 \%$, baik (10-20\%), sedang 


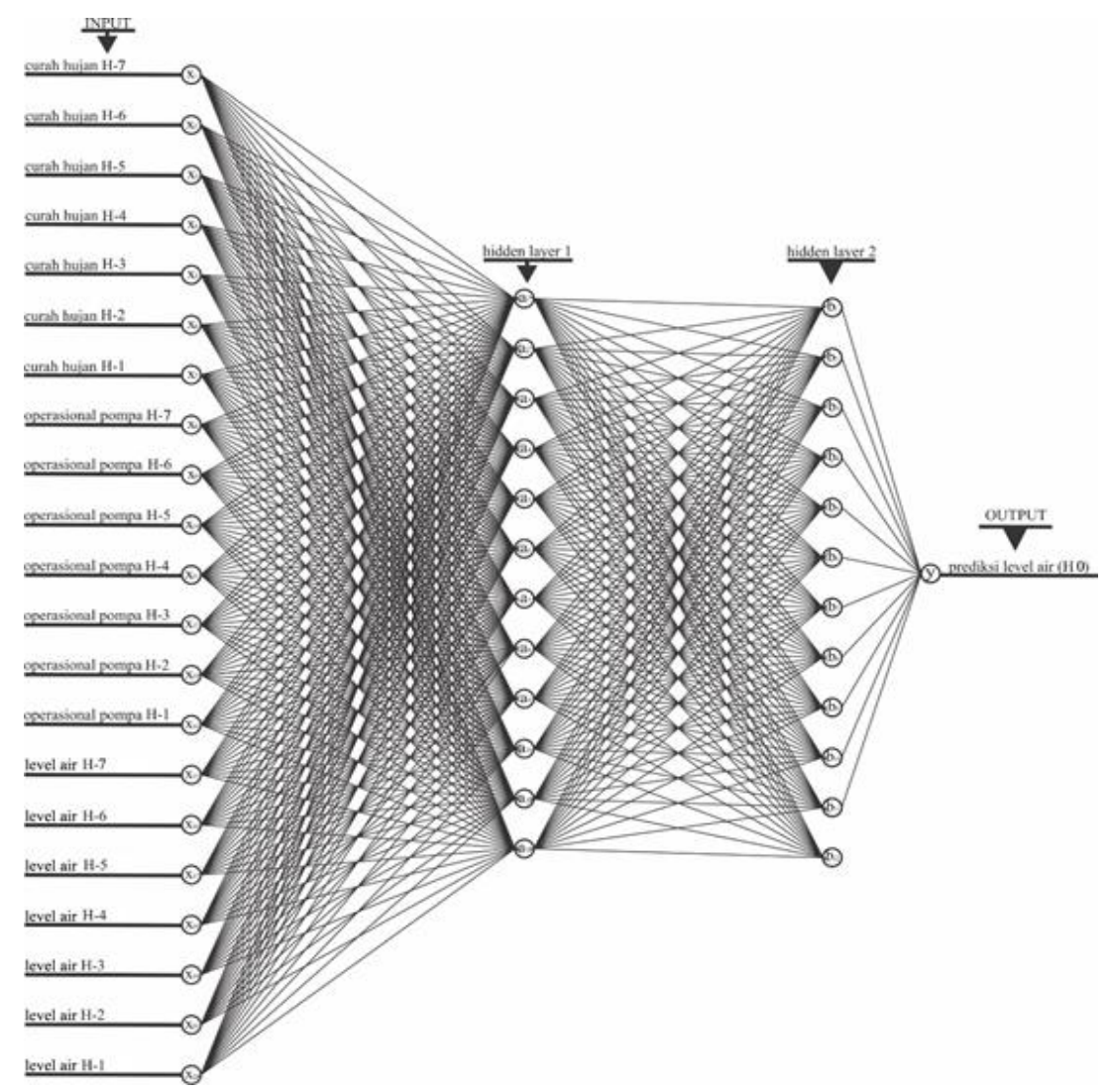

Gambar 5. Arsitektur Jaringan Saraf Tiruan Model Prediksi Level Air

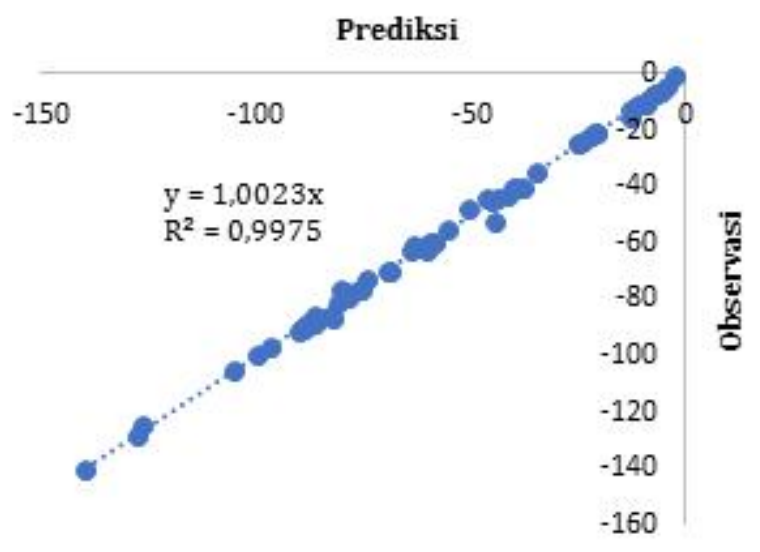

Gambar 6. Grafik Hubungan Prediksi dan Observasi Level Air

(20-30\%) dan buruk (>30\%) (Haryanto et al 2020). Sedangkan nilai RMSE sebesar $1,6 \mathrm{~cm}$ menjelaskan bahwa sedikit kesalahan yang terjadi pada pembuatan model prediksi level air.

\subsection{Pengujian Keakuratan Model Jaringan Saraf Tiruan}

Pengujian ini bertujuan untuk mengetahui kehandalan dari JST yang telah dibangun, apakah mampu mengidentifikasi input yang belum pernah diterima sebelumnya. Pengujian pada penelitian ini dilakukan untuk membuktikan apakah hasil yang diperoleh dalam hal ini output level air sesuai dengan nilai pengukuran sebenarnya.

Pada Gambar 7a hasil pengujian menunjukkan bahwa nilai RMSE diperoleh sebesar $1,99 \mathrm{~cm}$, RRMSE sebesar $-4.1 \%$ dan $\mathrm{R}^{2}$ sebesar 0,96 . Nilai $\mathrm{R}^{2}$ sebesar 0,96 dan RRMSE sebesar $-4,1 \%$ menjelaskan bahwa hasil prediksi yang dilakukan dalam pembuatan model memiliki 


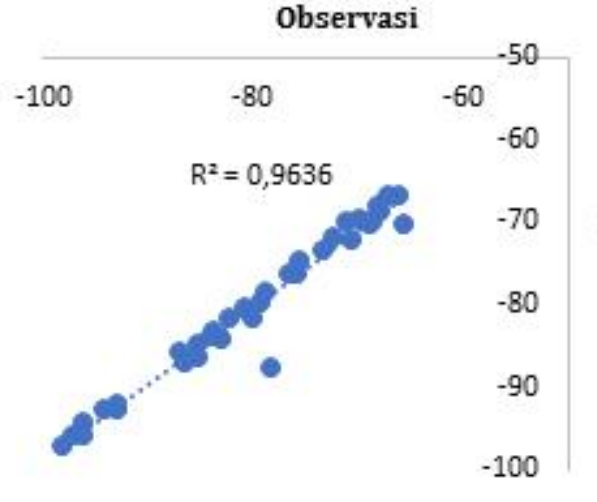

a

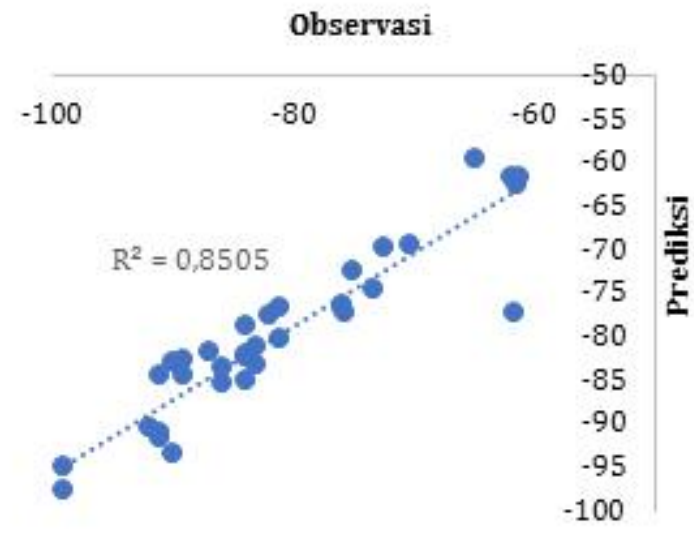

b

Gambar 7. Grafik Hubungan Prediksi dan Observasi Level Air pada (a) Musim Kemarau dan (b) Musim Hujan

kemampuan yang baik dalam megidentifikasi besaran target atau output yang keluar dari nilai observasi. Sedangkan nilai RMSE sebesar 1,99 $\mathrm{cm}$ menjelaskan bahwa hanya sedikit kesalahan yang terjadi pada hasil prediksi terhadap target yang telah ditentukan. sebelumnya sehingga dapat disimpulkan bahwa pembuatan model JST sudah berjalan dengan baik dalam memprediksi level air pada musim kemarau.

Pada Gambar $7 \mathrm{~b}$ hasil pengujian menunjukkan bahwa nilai RMSE diperoleh sebesar $4,2 \mathrm{~cm}$, RRMSE sebesar $-5.2 \%$ dan $R^{2}$ sebesar 0,85 . Nilai RRMSE sebesar $-5,2 \%$ menjelaskan bahwa model JST yang dibangun sudah sangat baik dalam memprediksi level air. Sedangkan nilai RMSE 4,2 cm menjelaskan bahwa hanya sedikit kesalahan yang terjadi pada hasil prediksi terhadap besaran target yang telah ditentukan sebelumnya. Nilai koefisien determinasi sebesar 0,85 menjelaskan bahwa hanya kurang $20 \%$ data hasil prediksi yang tidak sesuai dengan data observasi. Hasil prediksi yang tidak sesuai pada musim hujan dikarenakan beberapa faktor diantaranya terkait dengan optimalisasi kinerja pompa dan perawatan saluran drainase yang dilakukan.

\section{KESIMPULAN}

Model prediksi yang dibuat dapat memudahkan dalam memprediksi level air secara tepat, akurat dan dapat memprediksi nilai observasi lain yang belum digunakan dalam pembuatan model.
Pengujian keakauratan model secara aktual menandakan bahwa model prediksi yang dibangun dapat digunakan dengan baik dalam segala kondisi pada musim kemarau atau hujan. Penggunaan sensor rain gauge dan ultrasonik pada alat AWS dapat diimplementasikan dengan baik berdasarkan uji kinerja yang telah dilakukan. Model JST yang dibangun untuk memprediksi level air berjalan dengan sangat baik dan akurat berdasarkan nilai yang diperoleh pada $\mathrm{R}^{2}$ sebesar 0,994, RMSE sebesar $1,6 \mathrm{~cm}$ dan nilai RRMSE sebesar $-2.8 \%$.

\section{DAFTAR PUSTAKA}

Armin, H. N., Gunadi, I., \& Widodo, C. E. 2017. Pengiriman Data Hasil Pengukuran Parameter Lingkungan Menggunakan Jaringan Seluler Dengan Raspberry Pi Sebagai Node. Youngster Physics Journal, 6(1): 48-61

Haryanto, A., Saputra, T. W., Telaumbanua, M., \& Gita, A. C. 2020. Application of Artificial Neural Network to Predict Biodiesel Yield from Waste Frying Oil Transesterification. Indonesian Journal of Science \& Technology, 5(1): 62-74.

Hermawan, A. 2006. Jaringan Syaraf Tiruan (Teori dan Aplikasi). Andi Offset. Yogyakarta. 
Sumardi. 2005. Penakar Curah Hujan Otomatis Menggunakan Mikrokontrole ATMEGA 32. Jurnal Teknik Elektro, 11(2): 84-90.

Suriadikarta, D. A. 2005. Pengelolaan Lahan Sulfat Masam Untuk Usaha Pertanian. Jurnal Litbang Pertanian, 24(1): 36-45.

Minnesota Board of Water Level and Soil Resource. 2013. Hidrologic Monitoring of Wetlands, Supplemental Guidance. United States.

Naik, P., \& Katti, K. 2018. Automatic Of Irrigation System Using IoT. International Journal of Engineering and Manufacturing Science, 8(1): 77-88.

Nugroho, B. D. A., \& Aliwarga, H. K. 2019. RiTx; Integrating among Field Monitoring System (FMS), Internet of Things (IOT) and agriculture for precision agriculture.
IOP Conference Series: Earth and Environmental Science 335(1).

Rani, S., \& Parekh, F. 2014. Application of Artificial Neural Network ( ANN) for Reservoir Water Level Forecasting, 3(7): 1077-1082.

Siang,J.J. 2005. Jaringan Syaraf Tiruan dan Pemrogramannya menggunakan Matlab. Andi Offset. Yogyakarta.

Tukidi. 2010. Karakter Curah Hujan Di Indonesia. Jurnal Geografi, 7(2): 136-145.

Winarna, Santoso, H., Yusuf, M. A., \& Sutarta, E. S. (2014). Pertumbuhan Tanaman Kelapa Sawit di Lahan Pasang Surut (Oil Palm Growth on Tidal Land). Prosiding Seminar Nasional Lahan Subobtimal 2014, September: 1-10. 